\title{
PENGARUH KEPADATAN KANDANG TERHADAP KONSUMSI RANSUM, PERTAMBAHAN BERAT TUBUH, DAN KONVERSI RANSUM BROILER UMUR 14-28 HARI DI CLOSED HOUSE
}

\author{
Stocking Density Effect on Feed Consumption, Body Weight Gain, and Feed Conversion Ratio of \\ Broiler Aged 14-28 Days in Closed House
}

Siti Mariyam, Syahrio Tantalo, Riyanti, dan Dian Septinova

Departement of Animal Husbandry, Faculty of Agriculture, University of Lampung Jl. Prof. Dr. Soemantri Brojonegoro No.1 Gedong Meneng Bandar Lampung 35145

e-mail : sitimariyam358@gmail.com

\begin{abstract}
This research aimed : 1) to investigate the effect of stocking density on feed consumption, body weight gain, and feed conversion rate of broiler aged 14-28 days in closed house; 2) to determaine the best stocking density on feed consumption, body weight gain, and feed conversion ratio of broiler aged 1428 days in closed house. This research was conducted in closed house of PT. Charoen Pokphand (Kandang Bandara 2) located in Bangun Sari area of Way Sari village, Natar district, South Lampung regency. This research was conducted for 28 days, with rearing broiler from day $1^{\text {st }}-13^{\text {th }}$ was without treatment, and then from day $14^{\text {th }}$-harvest with treatments, that was conducted in April 2019-May 2019. This research used completely randomized design with 4 treatments $(15,17,19$, and 21 stocking density of chickens $\mathrm{m}^{-2}$ ) and 5 replications. Data obtained was analyzed using analysis on variance at $5 \%$ levels of significance and followed by Duncan's Multiple Range Test. Results showed that different stocking density of $15,17,19$, and 21 chickens $\mathrm{m}^{-2}$ affected $(\mathrm{P}<0.05)$ on feed consumption (with feed consumption of broiler of stocking density of 15 chickens $\mathrm{m}^{-2}$ was significantly $(\mathrm{P}<0.05)$ lower than those of 17,19 , and 21 chickens $\left.\mathrm{m}^{-2}\right)$, but it did not affect $(\mathrm{P}>0.05)$ on body weight gain and feed conversion ratio of broiler in closed house.
\end{abstract}

Keywords: Body weight gain, Closed house, Feed consumption, Feed convertion rate, Cage density

\begin{abstract}
ABSTRAK
Penelitian ini bertujuan untuk: 1) mengetahui pengaruh kepadatan kandang terhadap konsumsi ransum, pertambahan berat tubuh, dan konversi ransum broiler di closed house; 2) mengetahui kepadatan kandang yang terbaik terhadap konsumsi ransum, pertambahan bobot tubuh, dan konversi ransum broiler di closed house. Penelitian ini dilaksanakan di closed house PT. Charoen Pokphand (Kandang Bandara 2) yang terletak di Dusun Bangun Sari, Desa Way Sari, Kecamatan Natar, Kabupaten Lampung Selatan. Penelitian dilakukan selama 28 hari, dengan pemeliharaan broiler umur 1-13 hari tanpa perlakuan, kemudian pada umur 14 hari-panen diberi perlakuan, yang dilakukan pada April 2019 -Mei 2019. Penelitian ini menggunakan Rancangan Acak Lengkap dengan empat perlakuan dan lima ulangan yaitu kepadatan kandang 15 ekor $\mathrm{m}^{-2}(\mathrm{R} 1)$, kepadatan kandang 17 ekor $\mathrm{m}^{-2}(\mathrm{R} 2)$, kepadatan kandang 19 ekor $\mathrm{m}^{-2}$ (R3), dan kepadatan kandang 21 ekor $\mathrm{m}^{-2}$ (R4). Data yang diperoleh dianalisis menggunakan analisis ragam pada taraf $5 \%$ dan apabila dari analisis ragam menunjukkan bahwa pengaruh perlakuan terhadap peubah nyata pada taraf 5\%, maka analisis dilanjutkan dengan uji jarak berganda Duncan. Hasil analisis ragam menunjukkan bahwa kepadatan kandang $15,17,19$, dan 21 ekor $\mathrm{m}^{-2}$ berpengaruh nyata $(\mathrm{P}<0,05)$

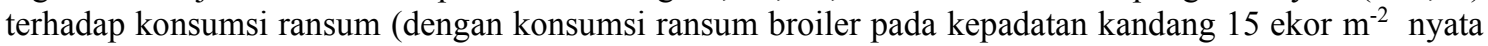
$(\mathrm{P}<0,05)$ lebih rendah dari konsumsi ransum broiler pada kepadatan kandang 17, 19, dan $\left.21 \mathrm{ekor} \mathrm{m}^{-2}\right)$ dan berpengaruh tidak nyata $(\mathrm{P}>0,05)$ terhadap pertambahan berat tubuh dan konversi ransum broiler di closed house.
\end{abstract}

Kata kunci: Closed house, Kepadatan kandang, Konsumsi ransum, Konversi ransum, Pertambahan berat tubuh 


\section{PENDAHULUAN}

Salah satu sumber protein hewani adalah daging broiler. Daging broiler banyak dipilih karena dari sisi harga lebih ekonomis dibandingkan dengan harga daging lainnya. Daging broiler juga banyak tersedia di pasaran, mulai dari pasar tradisional hingga supermarket. Perkembangan industri peternakan unggas berbanding lurus dengan perkembangan teknologi yang mendukung keberlangsungan usaha ternak broiler seperti perkandangan salah satunya adalah closed house.

Penggunaan closed house memungkinkan peternak menjadi lebih mudah untuk mengatur kondisi lingkungan terutama suhu dan kelembaban. Apabila suhu dan kelembaban kandang sudah terkontrol maka diduga broiler akan tetap merasa nyaman dengan kepadatan kandangnya yang ditingkatkan. Peningkatan kepadatan kandang berbanding lurus dengan peningkatan suhu dan kelembaban dalam kandang. Peningkatan suhu kandang mengakibatkan ayam menjadi stres, meningkatkan konsumsi minum dan menurunkan konsumsi ransum sehingga laju pertumbuhan akan terhambat (Fadilah, 2012). Kepadatan kandang yang tidak sesuai akan memberikan dampak yang negatif terhadap performa broiler. Kepadatan kandang yang melebihi kebutuhan optimal dapat menurunkan konsumsi ransum dan meningkatkan konversi ransum yang menyebabkan terhambatnya pertumbuhan ternak dan menurunnya berat akhir (Suprijatna dkk., 2005).

Penggunaan kandang closed house akan memudahkan untuk memberikan kondisi lingkungan yang sesuai dengan kebutuhan broiler, terutama suhu dan kelembaban kandang. PT. Charoen Pokphand telah menerapkan kepadatan kandang dengan kisaran 13-17 ekor m2. Tingkat kepadatan kandang closed house bisa mencapai 2-3 kali kandang open house. Jika kandang open house per meter perseginya hanya mampu menampung 6-8 ekor ayam, maka kandang closed house bisa menampung 14-18 ekor ayam per meter persegi (Alam, 2019). Menurut Info Medion (2019), kepadatan kandang open house berkisar $13-15 \mathrm{~kg} \mathrm{~m}^{-2}$ dan saat menggunakan closed house kepadatan kandang akan meningkat hampir 2 kali yaitu mencapai 23-30 $\mathrm{kg} \mathrm{m}^{-2}$ (13-18 ekor $\mathrm{m}^{-2}$ dengan berat badan berkisar $1,7 \mathrm{~kg} / \mathrm{ekor})$.
Kepadatan kandang di closed house diharapkan dapat ditingkatkan dibandingkan dengan kandang opened house, karena kandang closed house sudah direkayasa sedemikian rupa agar keadaan dalam kandang dapat diatur sesuai dengan kebutuhan ternak. Tingkat kepadatan kandang broiler di closed house sudah beragam, namun belum diketahui berapa tingkat kepadatan terbaik yang tetap menghasilkan performa yang baik terhadap broiler, sehingga perlu dilakukan penelitian mengenai pengaruh tingkat kepadatan terhadap performa (konsumsi ransum, pertambahan berat tubuh, dan konversi ransum) broiler di closed house.

\section{MATERI DAN METODE}

Penelitian ini dilaksanakan di closed house PT. Charoen Pokphand (Kandang Bandara 2) di Dusun Bangun Sari, Desa Way Sari, Kecamatan Natar, Kabupaten Lampung Selatan. Penelitian dilakukan selama 28 hari. Pelaksanaan penelitian dimulai dengan memelihara DOC hingga umur 13 hari di dalam kandang tanpa sekat bersama dengan DOC selain broiler penelitian, kemudian perlakuan dilakukan selama 14 hari saat broiler umur 14-28 hari, pada April-Mei 2019.

\section{Bahan dan Alat}

Bahan yang digunakan adalah DOC broiler CP 707 sebanyak 360 ekor Perlakuan perbedaan kepadatan kandang diterapkan pada broiler umur 14-28 hari. Ransum yang digunakan adalah ransum broiler komersil kode H0O untuk fase starter (umur 1-13 hari) dan H11 untuk fase finisher (umur 14 hari -panen). Peralatan yang digunakan untuk penelitian ini adalah kandang (closed house) beserta peralatan yang ada di dalamnya, diantaranya adalah 20 petak sekat kawat, baby chick feeder, hanging feeder, nipple drinker, timbangan digital, heater, alat kebesihan, thermohygrometer, desinfektan,,dan alat tulis

\section{Metode \\ Rancangan Percobaan}

Penelitian ini menggunakan rancangan acak lengkap (RAL) yang terdiri dari 4 perlakuan dan 5 ulangan. Perlakuan yang diberikan antara lain kepadatan kandang 15 ekor $\mathrm{m}^{-2}$ (R1), kepadatan kandang 17 ekor $\mathrm{m}^{-2}$ (R2), kepadatan kandang 19 ekor $\mathrm{m}^{-2}$ (R3), dan kepadatan kandang 21 ekor $\mathrm{m}^{-2}(\mathrm{R} 4)$. 


\section{Analisis Data}

Data dianalisis ragam pada taraf $5 \%$, bila menunjukkan pengaruh yang nyata pada taraf $5 \%$ maka dilanjutkan dengan uji jarak berganda Duncan (Stell dan Torrie, 1995).

\section{Peubah yang Diamati}

Peubah yang diamati pada penelitian ini adalah konsumsi ransum, pertambahan berat tubuh, dan konversi ransum. Konsumsi ransum dihitung dengan cara mengurangi jumlah ransum yang diberikan salama satu minggu dengan sisa ransum pada akhir minggu. Pertambahan berat tubuh dihitung dengan cara menurangi bobot tubuh ayam akhir minggu dengan bobot awal minggu. Konversi ransum dihitung berdasarkan perbandingan antara jumlah konsumsi ransum (g/ekor/minggu) dan pertambahan berat tubuh (g/ekor/minggu) setiap minggu (Nova dkk., 2015).

\section{HASIL DAN PEMBAHASAN}

\section{Pengaruh Perlakuan terhadap Konsumsi Ransum}

Hasil penelitian terhadap konsumsi ransum, pertambahan berat tubuh, dan konversi ransum disajikan pada Tabel 1. Rata-rata konsumsi ransum broiler selama penelitian berkisar antara 634,33 $\pm 26,89 \mathrm{~g} /$ ekor/minggu dan $694,53 \pm 20,93 \mathrm{~g} /$ ekor/minggu (Tabel 1). Hasil analisis ragam menunjukkan bahwa perlakuan kepadatan kandang 15, 17, 19, dan 21 ekor $\mathrm{m}^{-2}$ di closed house berpengaruh nyata $(\mathrm{P}<0,05)$ terhadap konsumsi ransum broiler. Berdasarkan hasil uji jarak berganda Duncan diperoleh bahwa konsumsi ransum broiler pada kepadatan 15 ekor $\mathrm{m}^{-2}(634,33 \mathrm{~g} /$ ekor/minggu $)$ nyata $(\mathrm{P}<0,05)$ lebih rendah dari 17 ekor $\mathrm{m}^{2}$ (671,70 g/ekor/minggu), dan 19 ekor $\mathrm{m}^{-2}$ (679,07 g/ekor/hari), dan 21 ekor $\mathrm{m}^{-2}$ (694,53 g/ekor/minggu).

Tabel 1. Rata-rata konsumsi ransum, pertambahan berat tubuh, dan konversi ransum broiler penelitian

\begin{tabular}{lcccc}
\hline \multirow{2}{*}{\multicolumn{1}{c}{ Peubah }} & \multicolumn{4}{c}{ Perlakuan } \\
\cline { 2 - 5 } & P1 & P2 & P3 & P4 \\
\hline $\begin{array}{l}\text { Konsumsi ransum } \\
\text { (g/ekor/minggu) }\end{array}$ & $634,33 \pm 26,89^{\mathrm{a}}$ & $671,70 \pm 26,28^{\mathrm{b}}$ & $679,07 \pm 22,74^{\mathrm{b}}$ & $694,53 \pm 20,93^{\mathrm{b}}$ \\
$\begin{array}{l}\text { Pertambahan berat } \\
\text { tubuh (g/ekor/minggu) }\end{array}$ & $342,21 \pm 18,08$ & $355,50 \pm 23,24$ & $353,00 \pm 12,65$ & $365,33 \pm 14,74$ \\
Konversi ransum & $1,85 \pm 0,02$ & $1,89 \pm 0,08$ & $1,92 \pm 0,05$ & $1,90 \pm 0,06$ \\
\hline
\end{tabular}

Keterangan :

Huruf superscript yang berbeda dalam baris rata-rata menunjukkan berbeda nyata $(\mathrm{P}<0,05)$.

P1 : kepadatan kandang 15 ekor $\mathrm{m}^{-2}$

P2 : kepadatan kandang 17 ekor $\mathrm{m}^{-2}$

P3 : kepadatan kandang 19 ekor $\mathrm{m}^{-2}$

P4 : kepadatan kandang $21{\text { ekor } \mathrm{m}^{-2}}^{-2}$

Konsumsi ransum broiler pada kepadatan kandang 15 ekor $\mathrm{m}^{-2}$ nyata lebih rendah daripada konsumsi ransum broiler pada kepadatan kandang 17, 19, 21 ekor $\mathrm{m}^{-2}$. Hal ini karena faktor kepadatan kandang mempengaruhi tingkat nafsu makan pada broiler. Menurut Qisthon dan Kurtini (2016), suara ketukan pada waktu ayam makan bukan hanya sekedar suara makan, tetapi sangat berpengaruh pada nafsu makan ayam lain yang mendengarnya. Nafsu makan juga terjadi bila ayam melihat ayam lain makan, ayam akan ikut makan meskipun sudah kenyang (tembolok penuh). Sebaliknya ayam yang sedang lapar (tembolok kosong) bila dimasukkan ke dalam kelompok yang kenyang, maka makannya akan sedikit dan seolah-olah tidak lapar. Berdasarkan uraian tersebut, hingga batas kepadatan kandang 21 ekor $\mathrm{m}^{-2}$ terlihat bahwa semakin tinggi kepadatan kandang akan membuat ayam banyak mengkonsumsi ransum, karena ayam semakin banyak melihat ayam lain yang ada di petaknya sehingga ayam akan saling melihat saat makan yang akan menyebabkan keinginan ayam untuk konsumsi ransum semakin tinggi.

Konsumsi ransum broiler pada kepadatan kandang 17, 19, dan 21 ekor $\mathrm{m}^{-2}$ yang relatif sama menunjukkan sampai batas 21 ekor $\mathrm{m}^{2}$ ayam tidak mengalami stres. Pada kondisi kepadatan kandang 21 ekor $\mathrm{m}^{-2}$ ayam masih dalam keadaan normal, sehingga ayam akan selalu berusaha mempertahankan keseimbangan suhu tubuhnya, dalam hal ini secara konstan memproduksi panas dan mengeluarkan panas ke lingkungannya. Fakta penelitian menunjukkan bahwa ayam sampai 21 ekor $\mathrm{m}^{-2}$ tidak mengalami stres karena terkondisi 
oleh lingkungan closed house. Tamalludin (2012) menjelaskan bahwa kondisi lingkungan di dalam closed house dapat diatur secara otomatis sehingga memenuhi kondisi ideal yang dibutuhkan untuk bisa tumbuh secara optimal. Di dalam closed house juga terdapat ventilasi berupa inlet dan blower yang dapat mempengaruhi suhu dan kelembaban dalam kandang. Priyatno (2002) menjelaskan bahwa ventilasi merupakan jalan keluar masuknya udara sehingga udara segar dari luar dapat masuk untuk menggantikan udara yang kotor di dalam kandang.

Rata-rata suhu dan kelembaban kandang selama penelitian adalah $26,98^{\circ} \mathrm{C}$ dan $83,29 \%$. Hal ini berarti kondisi suhu dan kelembaban kandang penelitian berada dalam heat stress danger zone (zona bahaya terkena stres panas) namun suhu dan kelembaban tersebut bukan suhu dan kelembaban yang dirasakan oleh ayam seperti penjelasan Info Medion (2019) menyatakan bahwa dalam closed house terdapat chilling effect yaitu efek penurunan suhu yang dirasakan ayam akibat kecepatan angin yang berhembus. Semakin tinggi angin berhembus, maka chilling effect yang dirasakan semakin besar atau suhu efektif semakin rendah. Suhu efektif adalah suhu yang dirasakan oleh tubuh ayam yang dipengaruhi oleh suhu ruangan (suhu yang terdeteksi di termometer), kelembaban, dan kecepatan angin dalam kandang (yang mengenai tubuh ayam).

Standar konsumsi ransum menurut Cobbvantress (2018) selama 14 hari pemeliharaan (umur 14-28 hari) adalah $872 \mathrm{~g} /$ ekor/minggu. Hal ini lebih tinggi jika dibandingkan dengan rata-rata konsumsi ransum broiler pada penelitian ini yakni 669,91 g/ekor/minggu. Perbedaan konsumsi ransum ini diduga karena kandungan nutrisi ransum yang berbeda. Sesuai dengan penjelasan Wahju (2004) yang menjelaskan bahwa tingginya energi dalam ransum menentukan banyaknya ransum yang dikonsumsi. Energi metabolisme (EM) ransum yang digunakan saat perlakuan kepadatan kandang (fase finisher/umur 14 hari-panen) sebesar $3.613 \mathrm{kkal} / \mathrm{kg}$, lebih tinggi jika dibandingkan dengan Cobb-vantress (2018) sebesar 3.025-3.150 kkal/kg. Hal inilah yang menyebabkan konsumsi ransum broiler pada penelitian ini lebih rendah. Wahju (2004) menjelaskan bahwa ayam cenderung meningkatkan konsumsinya jika kandungan energi ransum rendah, dan sebaliknya konsumsi akan menurun jika kandungan energi ransum meningkat.

\section{Pengaruh Perlakuan terhadap Pertambahan Berat Tubuh}

Rata-rata pertambahan berat tubuh broiler selama penelitian antara 342,21 $\pm 18,08$ g/ekor/minggu dan $365,33 \pm 14,74$ g/ekor/minggu seperti tertera pada Tabel 1. Hasil analisis ragam menunjukkan bahwa perlakuan kepadatan kandang

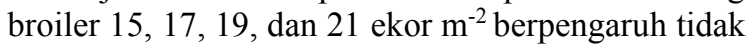
nyata $(\mathrm{P}>0,05)$ terhadap pertambahan berat tubuh broiler. Berdasarkan analisis ragam konsumsi ransum broiler pada kepadatan kandang 15 ekor $\mathrm{m}^{-2}$ lebih rendah dari konsumsi ransum broiler dengan kepadatan kandang 17, 19, dan 21 ekor $\mathrm{m}^{-2}$, namun pertambahan berat tubuh broiler relatif sama. Hal yang menyebabkan pertambahan berat tubuh pada kepadatan kandang 15 ekor $\mathrm{m}^{-2}$ sama dengan kepadatan kandang 17, 19, dan 21 ekor $\mathrm{m}^{-2}$, karena broiler dengan kepadatan kandang 15 ekor $\mathrm{m}^{-2}$ memiliki ruang yang lebih senggang atau luas untuk tumbuh dibandingkan dengan kepadatan kandang 17, 19, dan 21 ekor $\mathrm{m}^{-2}$. Hal ini sesuai dengan penjelasan Nova dkk (2015) yang menyatakan bahwa kepadatan kandang yang terlalu tinggi akan mengganggu pertumbuhan ayam, namun pada fakta penelitian ini hingga batas kepadatan kandang 21 ekor $\mathrm{m}^{-2}$ masih memiliki kemampuan yang sama untuk merubah ransum menjadi berat tubuh, hal ini dapat dilihat dari pertambahan berat tubuh yang tidak berbeda nyata $(\mathrm{P}<0,05)$.

Pertambahan berat tubuh yang berbeda tidak nyata $(\mathrm{P}>0,05)$ pada broiler dengan tingkat kepadatan kandang 15, 17, 19, dan 21 ekor $\mathrm{m}^{-2}$ diduga karena kepadatan kandang yang digunakan masih berada dalam batas toleransi broiler. Hal ini dikarenakan broiler dipelihara di closed house yang mampu mengkondisikan keadaan lingkungan sesuai dengan suhu dan kelembaban yang dibutuhkan oleh broiler. Hal tersebut sesuai dengan pendapat Alam (2019) yang menjelaskan bahwa stres lingkungan sangat minim pada kandang closed house. Rasyaf (2011) menjelaskan bahwa kepadatan kandang optimal akan semakin tinggi jika suhu udara kandang rendah. Penggunaan closed house membuat ayam akan tetap merasa nyaman sehingga proses pertumbuhan ayam tetap berjalan dengan baik meskipun pada perlakuan, kepadatan kandang yang berbeda-beda. Sulistyoningsih (2003) menerangkan bahwa kenyamanan akan tergantung pada toleransi terhadap kelembaban udara, temperatur udara di luar kandang, dan kecepatan angin.

Kondisi nyaman pada broiler memungkinkan proses pertambahan berat tubuh menjadi berjalan dengan baik, berbeda jika broiler berada pada kondisi stres. Waluyo (2016) menjelaskan bahwa stres akan muncul ketika ayam tidak bisa membuang panas dari dalam tubuhnya karena tingginya tingkat suhu di dalam kandang. Suprijatna dkk (2005) 
menambahkan bahwa peningkatan kelembaban dan suhu udara di dalam kandang mengakibatkan broiler menerima cekaman panas yang berakibat pada pengurangan energi oleh broiler dan menurunkan konsumsi ransum serta terjadi peningkatan konsumsi minum. Jika hal tersebut terus berlangsung dalam waktu yang lama akan berdampak pada rendahnya pertambahan berat tubuh broiler. Faktor lain yang diduga menjadi sebab pertambahan berat tubuh yang relatif sama pada tingkat kepadatan kandang 15,17,19, dan 21 ekor $\mathrm{m}^{-2}$ adalah konsumsi ransum yang relatif sama pada kepadatan kandang 17, 19, dan 21 ekor $\mathrm{m}^{-2}$. Pertambahan berat tubuh merupakan proyeksi dari ransum yang dikonsumsi oleh ayam tersebut, sehingga semakin tinggi konsumsi ransum maka pertambahan berat tubuh juga akan semakin tinggi. Rata-rata pertambahan berat tubuh broiler selama penelitian yaitu 354,01 g/ekor/minggu lebih rendah dari Cobb-vantress (2018) yaitu $58 \mathrm{~g} /$ ekor/hari atau $406 \mathrm{~g} /$ ekor/minggu. Santosa (2012) menjelaskan bahwa faktor-faktor yang mempengaruhi pertambahan berat badan pada unggas adalah spesies, strain, tipe produksi, jenis kelamin, suhu lingkungan, musim, mutu dan jumlah ransum, manajemen pemeliharaan, bentuk ransum, sistem pemberian ransum, dan berat awal.

\section{Pengaruh Perlakuan terhadap Konversi Ransum}

Secara statistik, konversi ransum dengan kepadatan kandang 15, 17, 19, dan 21 ekor $\mathrm{m}^{-2}$ tidak berbeda nyata $(\mathrm{P}>0,05)$. Berdasarkan penjelasan tersebut, maka dapat dikatakan bahwa hingga mencapai batas kepadatan kandang 21 ekor $\mathrm{m}^{-2}$, broiler masih memiliki kemampuan yang sama dalam mengubah ransum menjadi pertambahan berat tubuh sehingga angka konversi menjadi relatif sama. Konversi ransum broiler pada kepadatan kandang 15 ekor $\mathrm{m}^{-2}$ yang sama dengan konversi ransum broiler pada kepadatan kandang 17 ekor $\mathrm{m}^{-2}$ artinya bahwa perbedaan 2 ekor $\mathrm{m}^{-2}$ pada tingkat kepadatan kandang tersebut menyebabkan kondisi fisiologis ayam menjadi relatif sama yang diikuti dengan efisiensi penggunaan ransum yang relatif sama.

Rata-rata frekuensi pernafasan broiler penelitian adalah $58,27 \mathrm{kali} / \mathrm{menit}$, lebih tinggi dari Smith dan Mangkoewidjojo (1998), 20-35 $\mathrm{kali} / \mathrm{menit}$. Respon fisiologis dapat dijadikan salah satu acuan yang berdampak terhadap konversi ransum. Peningkatan respon fisiologis terjadi apabila terdapat peningkatan suhu dan kelembaban dalam kandang, kemudian menyebabkan terjadinya pemborosan energi dalam tubuh broiler. Menurut Gunawan dan Sihombing (2004), dalam kisaran suhu lingkungan optimum, ayam dapat menggunakan pakan lebih efisien karena ayam tidak mengeluarkan energi untuk mengatasi suhu lingkungan yang tidak normal. Pada suhu lingkungan yang lebih tinggi, ayam berusaha menjaga suhu tubuhnya dengan cara menyeimbangkan produksi panas dengan hilangnya panas. Sulistyoningsih (2003) menambahkan secara teori yang dikenal dengan zone thermoneutrality, yaitu kisaran temperatur produksi panas (Heat Production $/ \mathrm{HP})=$ hilangnya panas $($ Heat Loss $/ \mathrm{HL})$, artinya broiler tidak menggunakan energi untuk menyeimbangkan antara HP dengan HL sehingga broiler yang dipelihara efisiensinya optimal. Optimal dalam hal mengubah ransum menjadi berat tubuh.

Konversi ransum broiler pada kepadatan kandang 15 ekor $\mathrm{m}^{-2}$ juga relatif sama dengan konversi ransum broiler pada kepadatan kandang 19 dan 21 ekor $\mathrm{m}^{-2}$. Konsumsi ransum broiler pada kepadatan kandang 15 ekor $\mathrm{m}^{-2}$ nyata $(\mathrm{P}<0,05)$ lebih rendah dari konsumsi ransum broiler pada kepadatan kandang 17, 19, dan 21 ekor $\mathrm{m}^{-2}$, namun menghasilkan pertambahan berat tubuh yang relatif sama mulai dari 15 hingga 21 ekor $\mathrm{m}^{-2}$. Hal ini menunjukkan bahwa broiler pada kepadatan kandang 15 ekor $\mathrm{m}^{-2}$ memiliki kemampuan yang lebih baik untuk mengubah ransum menjadi berat tubuh dibandingkan dengan broiler pada kepadatan kandang 17, 19, dan 21 ekor $\mathrm{m}^{-2}$. Wahju (2004) menjelaskan bahwa semakin kecil angka konversi ransum menandakan ayam lebih baik dalam mengubah ransum menjadi daging.

Kepadatan kandang yang tinggi akan menyebabkan suhu kandang menjadi meningkat. Qurniawan dkk (2016) menjelaskan bahwa suhu dalam kandang merupakan gabungan panas lingkungan yang berasal dari radiasi matahari dan panas metabolisme dalam tubuh ayam yang dilepaskan ke lingkungan. Suhu udara yang tinggi akan menyebabkan ayam mengalami stres panas dan akan terjadi penurunan energi. Hal ini terjadi karena energi yang ada dalam tubuh ayam yang seharusnya dikonversi menjadi berat tubuh sudah digunakan terlebih dahulu untuk mengatasi kelebihan panas dalam tubuh ayam. Hasil penelitian kepadatan kandang tidak berbeda nyata $(\mathrm{P}>0,05)$ terhadap konversi ransum broiler. Hal tersebut diduga karena ayam dipelihara di closed house, sehingga suhu dalam kandang tetap memberikan kenyamanan bagi ayam meskipun kepadatan kandangnya tinggi. Closed house juga dilengkapi dengan blower, yang memungkinkan adanya aliran angin dalam kandang, sehingga kandang akan tetap terasa lebih dingin. Hal ini seperti yang dituliskan dalam Info Medion 
(2019), jika terdapat aliran udara maka suhu yang dirasakan oleh tubuh ayam akan lebih rendah, meskipun suhu termometer tinggi (chilling effect).

Rata-rata konversi ransum broiler penelitian di closed house adalah 1,89 lebih tinggi jika dibandingkan dengan standar Cobb-vantress (2018). Cobb-vantress menyatakan bahwa konversi ransum kumulatif untuk broiler umur 28 hari adalah 1,37. PT. Charoen Pokphand (2006) menyatakan bahwa konversi ransum untuk broiler CP 707 umur 4 minggu adalah 1,435. Menurut Lubis (1993), konversi ransum sangat dipengaruhi oleh kondisi ternak, daya cerna, jenis kelamin, bangsa, kualitas dan kuantitas ransum, serta faktor lingkungan.

\section{Simpulan}

\section{SIMPULAN DAN SARAN}

Simpulan yang diperoleh dari penelitian yang telah dilakukan adalah perlakuan kepadatan

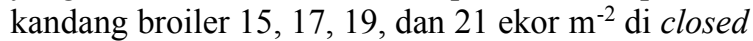
house berpengaruh nyata $(\mathrm{P}<0,05)$ terhadap konsumsi ransum (dengan konsumsi ransum broiler pada kepadatan kandang 15 ekor $\mathrm{m}^{-2}$ nyata $(\mathrm{P}<0,05)$ lebih rendah dari konsumsi ransum broiler pada kepadatan kandang 17, 19, dan 21 ekor $\mathrm{m}^{-2}$ ), tetapi tidak berpengaruh nyata $(\mathrm{P}>0,05)$ terhadap pertambahan berat tubuh dan konversi ransum.

\section{Saran}

Saran yang dianjurkan berdasarkan penelitian ini adalah peternak dapat menggunakan kepadatan kandang sampai dengan 21 ekor $\mathrm{m}^{-2}$ (kisaran bobot tubuh $\pm 1,1 \mathrm{~kg}$ pada umur 28 hari) atau $23,1 \mathrm{~kg} \mathrm{~m}^{-2}$ pada pemeliharaan broiler di closed house, karena konversi ransum yang relatif sama dengan kepadatan kandang 15, 17, dan 19 ekor $\mathrm{m}^{-2}$ sehingga menjadi lebih efisien dalam penggunaan ruang kandang.

\section{DAFTAR PUSTAKA}

Alam, S. 2016. Broiler Closed House. Majalah Infovet.

https://www.majalahinfovet.com/2016/04/ter ampil-mengoperasikan-broilerclosed.html?m=1 . Diakses pada 13 Maret 2019.

Cobb-vantress. 2018. Cobb500 Panduan Performan Broiler dan Nutrisi. Cobb. Indonesia.

Fadilah, R. 2012. Kunci Sukses Beternak Ayam Broiler di Daerah Tropis. AgroMedia Pustaka. Jakarta Selatan.

Gunawan dan D.T.H. Sihombing. 2004. Pengaruh suhu lingkungan tinggi terhadap kondisi fisiologis dan produktivitas ayam buras. Wartazoa 14 (1): $31-38$.
Info Medion. 2019. Closed house, solusi peningkatan performa ayam. https://info.medion.co.id/index.php/artikel/39 -tata-laksana/2305-closed-house-solusipeningkatan-performa-ayam. Diakses pada 11 Maret 2019.

Lubis, D. A. 1993. Ilmu Makanan Ternak. PT Pembangunan. Jakarta.

Nova, K., T.Kurtini, dan Riyanti. 2015. Manajemen Usaha Ternak Unggas. Buku Ajar. Jurusan Peternakan. Fakultas Pertanian. Universitas Lampung. Lampung.

Priyatno, M. A. 2002. Membuat Kandang Ayam. Penebar Swadaya. Jakarta.

PT. Charoen Pokphand Indonesia. 2006. Manajemen broiler modern. Kiat-kiat memperbaiki FCR. Technical Service dan Development Departement, Jakarta.

Qisthon, A dan T. Kurtini. 2016. Perilaku Ternak. Buku Ajar. Jurusan Peternakan. Fakultas Pertanian. Universitas Lampung.

Qurniawan,A., I.I.Arief., R.Arfan. 2016. Performans produksi ayam pedaging pada lingkungan pemeliharaan dengan ketinggian yang berbeda di Sulawesi Selatan. J. Veteriner 17(4): $622-633$.

Rasyaf, M. 2011. Panduan Beternak Ayam Pedaging. Kasinus. Yogyakarta.

Santosa. 2012. Faktor-faktor yang Memengaruhi Pertambahan Berat Tubuh Unggas. https://uripsantosa.wordpress.com/2012/06/2 9/faktor-yang-memengaruhi-pertambahanberat-tubuh-unggas . Diakses pada 17 April 2019.

Stell, R. G. D. dan J. H. Torrie. 1995. Prinsip dan Prosedur Statistika : Suatu Pendekatan Biometrik. Alih Bahasa Bambang Sumantri. PT. Gramedia. Jakarta.

Sulistyoningsih, M. 2003. Pengaruh Temperatur Lingkungan terhadap Ayam Broiler. Lontar 17 (1): $67-82$.

Suprijatna. E., U. Atmomarsono, dan K. Ruhyat. 2005. Ilmu Dasar Ternak Unggas. Penebar Swadaya. Jakarta.

Tamalludin, F. 2012. Ayam Broiler, 22 Hari Panen Lebih Untung. Penebar Swadaya. Jakarta.

Wahju, J. 2004. Ilmu Nutrisi Unggas. Edisi Ke-4. Universitas Gadjah Mada Press. Yogyakarta.

Waluyo, S dan M. Effendi. 2016. Beternak Ayam Broiler Tanpa Bau, Tanpa Vaksin Hemat Biaya dengan Pakan Fermentasi. Agromedia Pustaka. Jakarta. 

e-ISSN:2598-3067 